\title{
Membentuk Karakter Logis, Kritis, Kreatif dan Inovatif dalam Pembelajaran Matematika Melalui Pendekatan Saintifik
}

\author{
Yunni Arnidha ${ }^{1)}$,Fatahillah ${ }^{2)}$ \\ 1.yunniarnidha@umpri.ac.id, fatahillahpgsd@umpri.ac.id \\ Universitas Muhammadiyah Pringsewu Lampung
}

\begin{abstract}
Abstrak
Memiliki Sikap yang berorientasikan Pemikiran Logis, Kritis, Kreatif dan Inovatif pada peserta didik di tingkat Sekolah Dasar sangat penting untuk diwujudkan melalui berbagai program pembelajaran, salah satunya melalui Pembelajaran Matematika sebagai bidang keilmuan yang mencoba membentuk pola pikir, di mana karakter tersebut sangat berguna sebagai life skill peserta didik di era 4.0. ini. Makalah ini akan mencoba memberi dasar argumentative teoritis dan empiris mengenai bagaimana membentuk Karakter Logis, Kritis, Kreatif dan Inovatif dalam Pembelajaran Matematika di sekolah dasar melalui Pendekatan Saintifik. Adapun Metode Kajian yang akan dipergunakan adalah bersifat kualititatif dalam tradisi Fenomenologi dan Studi eksploratif tekstual, di mana kesimpulan yang didapat ialah, 1) Pembentukan Karakter dilakukan tidak hanya melalui internalisasi Pengetahuan belaka, akan tetapi diupayakan menciptakan pengalaman belajar; 2) Karakter Logis, Kritis, Kreatif dan Inovatif mampu menyikapi Persoalan Matematis, Langkah Pemecahan dan Solusi sehingga dapat diaplikasikan dalam kehidupan.
\end{abstract}

Kata Kunci : Karakter Logis, Kritis, Kreatif dan Inovatif, Pendekatan Saintifik, dan Pembelajaran Matematika.

\section{PENDAHULUAN}

Mengolah Pola Pikir untuk menumbuhkembangkan karakter yang berorientasi pada pemikiran logis, kritis, kreatif dan inovatif senantiasa menjadi bahan pemikiran dari segenap pendidik dari tingkat sekolah dasar sampai jenjang pendidikan tinggi. setiap program pendidikan atau mata pelajaran telah didesain sedemikian rupa agar mampu mengembangkan nilai sebagai penguat karakter, di mana hal inilah yang menjadi tujuan dari pendidikan itu di adakan. Seperti apa yang dikemukakan oleh Kosim (2012:87) mengutip makna Pendidikan dalam Undang-Undang Nomor 20/2003 tentang Sistem Pendidikan Nasional yang menyatakan bahwa Pendidikan merupakan bentuk kegiatan untik mengembangkan Potensi diri dalam pembentukan kepribadian yang diperlukan untuk masyarakat, bangsa dan negara.

Secara Cross Curricular Pendidikan karakter diupayakan pararel, berkesinambungan dan efektif, di mana pendidikan karakter merupakan segala upaya tenaga pendidik untuk mempengaruhi watak dan mentalitas Peserta didik melalui langkah-langkah pembelajaran di berbagai program pendidikan atau mata pelajaran yang ia berikan (Asmani, 2011:31). Karakter yang 
ditujukan untuk dibentuk adalah merupakan karakter yang memberikan bekal psikologis pada siswa dalam berperilaku di dalam kehidupannya. Suyitno (2012:1) menyatakan bahwa Pendidikan Karakter merupakan suatu keniscayaan yang harus dikembangkan demi sebuah perubahan. Selama ini Pendekatan Pembentukan Karakter lebih mengutamakan Mata Pelajaran Non Eksakta yang berorientasikan nilai-nilai humaniora seperti Pendidikan IPS, Pendidikan Kewarganegaraan dan Pendidikan Agama yang memang dari tujuan awalnya adalah untuk membentuk manusia seutuhnya. baik secara Psikologis dan spiritual. Padahal menurut Istiarno (Dewi, 2019:102) Pendidikan sebaiknya memberikan kompetensi; 1) Intelektual yaitu suatu bentuk kemampuan untuk berpikir, bernalar yang kreatif dan inovatif; 2) Personal yang mampu memiliki sikap jujur disiplin mandiri, kritis, dan bertanggungjawab; 3) Komunikatif kemampuan bahasa dan komunikasi 4) sosial budaya yakni kemampuan hidup bersama dan bekerjasama 5) Kinestetik sebagai bentuk penguasaan terhadap Ilmu Pengetahuan.

Bentuk dari sikap yang menyikapi berbagai fenomena yang terjadi maka sebaiknya penanaman karakter tidak hanya diterapkan dalam pembelajaran non Eksasta, akan tetapi perlu dikembangkan melalui pembelajaran Eksak seperti Matematika. Matematika merupakan hal penting untuk dikuasai individu generasi 4.0. untuk memberikan bekal tentang bagaimana cara berpikir, sehingga Peserta Didik mampu berdaya guna dalam kehidupan yang serba cepat dan mekanis berdasarkan kaidah-kaidah matematis. Matematika menurut Sumardyono (Murni, 2019: 1) adalah suatu Ilmu Pengetahuan yang memiliki karakteristik 1) berupaya membentuk Pola Pikir deduktif; 2) Mengajarkan simbol-simbol dan istilah sebagai hasil kesepakatan pada suatu aksioma; 3) Berobyek abstrak yang tergambar dalam fakta, konsep, operasi dan prinsip; 4) memiliki sistem belajar yang konsisten; 5) memperhatikan semesta pembicaraan atau topik.

Berkaca dari Konseptualisasi di Pembekalan Matematika diatas dapat dikatakan sebagai konseptualisasi cara berpikir yang sangat sistematis demi membentuk pola berpikir kognitif peserta didik mulai dari jenjang Pendidikan dasar, sehingga akan menjadi Karakter yang mumpuni di tengah era revolusi Industri 4.0. yang bergantung pada bantuan alat-alat digital. Maka dari itu Pendekatan saintifik menjadi andalan dalam pelaksanaan pembelajaran Matematika, di mana pendekatan ini menggunakan langkah-langkah yang berupa: Mengamati, Menanya, Mengumpulkan Informasi, Mengasosiasikan dan Mengomunikasikan, sehingga akan memberikan sensasi latihan pada peserta didik yang pada akhirnya menumbuhkembangkan karakter keilmuan.

Pendekatan Saintifik dijelaskan dalam Buku Panduan Teknis Pembelajaran dan Penilaian Pembelajaran di Sekolah Dasar (DIKDASMEN Kemendikbud RI, 2016: 21) sebagai Pendekatan Pembelajaran yang didesain agar siswa dapat secara aktif mengkosntruksikan konsep, prinsip atau teori melalui suatu tahapan kegiatan atau langkah yang berupa mengamati, menanya, menalar, dan menarik kesimpulan (mengasosiasi), kemudian dapat mengkomunikasikannya dengan inti dari semua konsep pembelajaran ini adalah aktivitas observasi.

Setelah melihat paparan yang disampaikan dalam latar belakang timbulah suatu pertanyaan yang dasar kajian pada makalah ini yakni: 1) bagaimana membentuk karakter logis, kritis, kreatif dan inovatif dalam pembelajaran 
matematika di sekolah dasar melalui pendekatan saintifik?; 2) dan karakter logis, kritis, kreatif, dan inovatif seperti apa yang terbentuk?

\section{METODE KAJIAN}

Penelaahan yang dilaksanakan pengkajian makalah menggunakan pendekatan bersifat kualitatif dalam Tradisi Fenomenologi secara Studi Eksploratif Tekstual. Pendekatan penelaahan Kualitatif dan Grounded Theorie dilakukan dengan maksud berusaha mengupas secara konseptual mengenai dasar-dasar tekstual dan teoritis mengenai apa dan bagaimana Pendekatan Saintifik dilakukan dalam Pembelajaran Matematika dilakukan untuk menumbuhkembangkan Karakter Logis, Kritis, Kreatif, dan Inovatif. Obyek pengkajian adalah bagaimana Pendekatan Saintifik dijalankan dalam Pembelajaran Matematika dilaksanakan secara empiris dilakukan di kelaskelas, dengan melihat melalui buku-buku tekstual yang mengkaji bagaimana pembelajaran dilaksanakan. Sedang subyek kajian Guru sebagai Tenaga Pengajar yang menjadi komponen insan utama pembelajaran

Adapun teknis analisis Data dilakukan melalui Teknis Analisis Domain dengan mengutamakan hasil pengamatan fenomenologis terhadap obyek penelitian yang menjadi fokus pembahasan. Dengan demikian pengkajian Makalah ini akan melalui langkah-langkah sebagai berikut; 1) ditelaah konsepsi karakter logis, kritis, kreatif, dan inovatif yang hendak dicapai pendidikan karakter dalam sosok siswa sekolah dasar.; 2) ditelaah konsepsi pembentukan karakter dalam pembelajaran matematika. 3) ditelaah gambaran konsepsi dan karakteristik pendekatan saintifik dalam pembelajaran secara umum dan secara khusus dalam pembelajaran matematika. 4) menguraikan deskripsi korelasi teoritis mengenai bagaimana pendekatan saintifik dijalankan pada pembelajaran matematika dalam menumbuhkan karakter logis, kritis, kreatif, dan inovatif; dicari simpulan dan konklusi mengenai deskrisp karakter logis, kritis, kreatif, dan inovatif.

\section{PEMBAHASAN}

\section{Memahami Karakter Logis, Kritis, Kreatif, dan Inovatif dalam Sosok Peserta didik.}

Menurut Kamus besar Bahasa Indonesia Kata "Logis" dalam kosakata Indonesia memiliki makna sesuai dengan logika; benar menurut penafsiran; masuk akal. Sedangkan kata Kritis, Kreatif, dan Inovatif dalam konteks pembelajaran dimaknai berturut-turut sebagai berikut; 1) Kritis : tajam dalam penaganalisaan; 2) Kreatif: memiliki kemampuan untuk mencipta; 3) Inovatif : memiliki kemampuan untuk melakukan pembaharuan (kbbi.kemendikbud.go id: diakses tanggal 16 Januari 2021).

Berpikir Logis dapat dikatakan menjadi sasaran utama dalam setiap upaya Pendidikan dan pengajaran, karena sasaran awal dari Pendidikan dan pembelajaran untuk membentuk orientasi kognitif peserta didik yang menjadi bekal orientasi selanjutnya yakni Afektif dan Psikomotorik dalam taksonomi blomm. Orientasi Kognitif mempunyai pengertian berfikir dan mengamati dalam rangka memperoleh pengetahuan, kegiatan siswa yang termasuk pada kognitif 
ini meliputi; mendeteksi, menafsirkan, mengelompokkan dan mengingat informasi.

Setiap upaya mendapatkan pengetahuan harus dilakukan melalui cara tertentu, sehingga kan mendapatkan pengetahuan yang dapat dipertanggungjawabkan kebenarannya Terdapat dua jenis penalaran logis yang harus dikuasai para siswa yakni deduktif dan induktif. Penalaran deduktif mensyaratkan pemikiran dari prinsip-prinsip atau proporsi dari bersifat umum ke suatu kesimpulan spesifik yang sahih, sedangkan induktif adalah cara atau teknik bagaimana menarik kesimpulan dari yang bersifat kasus per kasus atau khusus, yang kemudian digeneralisasi sehingga dapat diterima sebagai proporsi yang bersifat umum (Saadulloh, 2004: 91)

Dari upaya penalaran tersebut mereka akan membentuk apa yang dinamakan pengetahuan, apabila dirunut dari sumbernya maka akan didapat; a) Pengetahuan wahyu (revealed knowledge) : pengetahuan yang berasal dari ajaran KeTuhanan berupa Agama; b) Pengetahuan intuitif (intuitif knowledge) yakni suatu pengetahuan yang timbul dari kesadaran manusia ketika berpikir; c) Pengetahuan Rasional (rational knowledge) yakni pengetahuan yang didapat dari pengolahan 'persepsi akal terhadap suatu fenomena; d) Pengetahuan empiris (empirical knowledge) : dapat dikatakan sebagai pengetahuan yang didapat dari kesan panca indera yang menangkap secara langsung lingkungan sekitar atau hal yang dialami e) Pengetahuan Otoritas (authoritative knowledge) yakni pengetahuan yang didapat dari sumber yang memiliki wewenang atau berhak untuk menentukan kebenaran atau pengetahuan tersebut (Saadulloh, 2004:33).

Supardan (2008:46-47) terdapat teori-teori yang menyatakan apakah pengetahuan itu memiliki kebenaran atau tidak; 1) Teori Korespondensi (Correspondence Theory) teori menyatakan sebuah pernyataan atau pengetahuan akan dikatakan benar apabila sesuai antara apa yang dinyatakan dengan realitanya dalam pengetahuan tersebut contoh: Bangun Datar Segitiga Siku-siku memiliki sudut 90, 2) Teori Koherensi (Coherence Theory) Pernyataan Pengetahuan akan dianggap benar apabila dapat diterima secara logis sebagai kebenaran oleh si penerima pengetahuan tanpa memperdulikan realitanya Contoh: teori konspirasi atau Bumi Datar (Flat Earth). 3) Teori Pragamatisme yakni pengetahuan akan dianggap sebagai suatu kebenaran apabila bermanfaat bagi si penerima pengetahuannya.

Menurut Sanjaya (2008:102) seperti yang dikemukakan Bloom terdapat 6 (enam) tingkatan dalam mengolah kemampuan berpikir atau penalaran terhadap yakni; 1) Mengetahui dengan mengingat; 2) Memahami; 3) Menerapkan; 4) Menganalisis; 5) Mensintesa; dan 5) mengevaluasi. Kesemua tahapan itu Penalaran yang diharapkan pengetahuan yang dihasilkan dapat diterima kebenarannya secara universal. Dari Penjelasan di atas, dapat dikatakan setiap Peserta Didik sebagai insan akademis dari mulai tingkat sekolah dasar samapi pendidikan tinggi diupayakan untuk selalu dipacu dan dimotivasi oleh setiap pendidik dalam hal ini guru.

Bukankah guru merupakan Pendidik Profesional yang memiliki tugas utama untuk mengajar, membimbing, mengarahkan, melatih, menilai, dan mengevaluasi peserta didik (Kunandar, 2009:54). Selanjutnya guru juga dituntut dapat menumbuhkembangkan kemampuan berpikir kritis sebagai tahapan 
pengembangan kognitif siswa dalam pembelajaran mengumpulkan berbagai pengetahuannya. Abdullah (2016: 73) menjelaskan bahwa berpikir kritis adalah suatu aktivitas mental yang menggunakan kemampuan akal untuk memahami, merumuskan masalah, mengumpulkan informasi, dan menganalisis Informasi sehingga dapat mengambil suatu Hipotesis, dugaan, prediksi, dan asumsi.

Aktivitas mental yang dimaksud itu adalah aktivitas yang berupa; a) Memahami dan Merumuskan masalah; b) Mengumpulkan informasi yang diperlukan dan dapat dipercaya; c) menganalisis informasi sehingga dapat mengklarifikasi masalah; d) merumuskan hipotesis; e) membuktikan hipotesis melalui kaida-kaidah logika; f) menarik kesimpulan; g) Melakukan Evaluasi; h) mengambil keputusan;i) Melakukan Estimasi dan Generalisasi. (Abdullah, 2016: 73). Berpikir kritis menjadi suatu capaian dalam pembelajaran karena akan membangun pemikiran yang berupa gagasan atau ide dari sebuah prinsip atau teori yang dapat pergunakan dalam kehidupan peserta didik kelak sebagai life skill. (Azizah dkk, 2018:62). Dikarenakan dapat melahirkan ide gagasan setelah pada sosok Peserta Didik ditemukan kemampuan berpikir logis dan kritis, diharapkan Sikap Kreatif akan muncul.berbagai macam Inovasi yang akan mengubah berbagai paradigma maupun pemikiran.

Inovasi dimaknai sebagai gagasan, tindakan, atau barang yang dianggap baru oleh seseorang (Tafsir, 2014:25). Gagasan itu kemudian akan menghasilkan apa yang dgisebut sebagai Discovery dan Invention. Discovery adalah penemuan sesuatu yang sebenarnya sudah ada tetapi belum diketahui orang, seperti penemuan benua Amerika oleh bangsa Eropa, dan Inovasi merupakan hasil kreasi baru manusia. Kedua hal tersebut diatas membutuhkan kemampuan manusia untuk melakukan daya cipta yang dilatarbelakangi sikap atau perilaku kreatif, maka sifat kreatif menjadi sangat penting untuk ditumbuhkembangkan. Sifat Kreativitas dalam diri Anak merupakan suatu perwujudan dari gagasan atau teori yang bersumberkan pemikiran dan olah pikir. Karena itu haruslah dikembangkan sejak dini (Sari dkk, 2020:47).William (Munandar, 2015:24, Sari dkk, 2020:47) mengkategorikan kreativitas dalam dalam dua bentuk yakni; a) kategori pengetahuan berkaitan kreativitas yang dikaitkan dengan bagaimana seseorang berpikir kreatif, b) kategori sikap berkaitan dengan sebuah kreativitas atas dasar perilaku yang ditunjukkan. Maka dari itu pengembangan kreativitas haruslah bersandar pada apa bagaimana mengubah; Pola pikir, pandangan atau sikap hidup, dan perilaku yang mendukung.

Apabila kita gambarkan terdapat keterkaitan karakter logis, kritis, kreatif dan Inovatif, bahwa pemikiran logis yang selalu menjadi sandaran dalam berpikir pada peserta didik akan membentuk pemikiran kritis ketika menyikapi sesuatu hal sebagai kesan pengetahuan, sehingga ia akan selalu berkreasi dan berinovasi terhadap apapun yang berkaitan dengan pembelajarannya. Untuk lebih jelas lihat Gambar 1 skema berikut. 


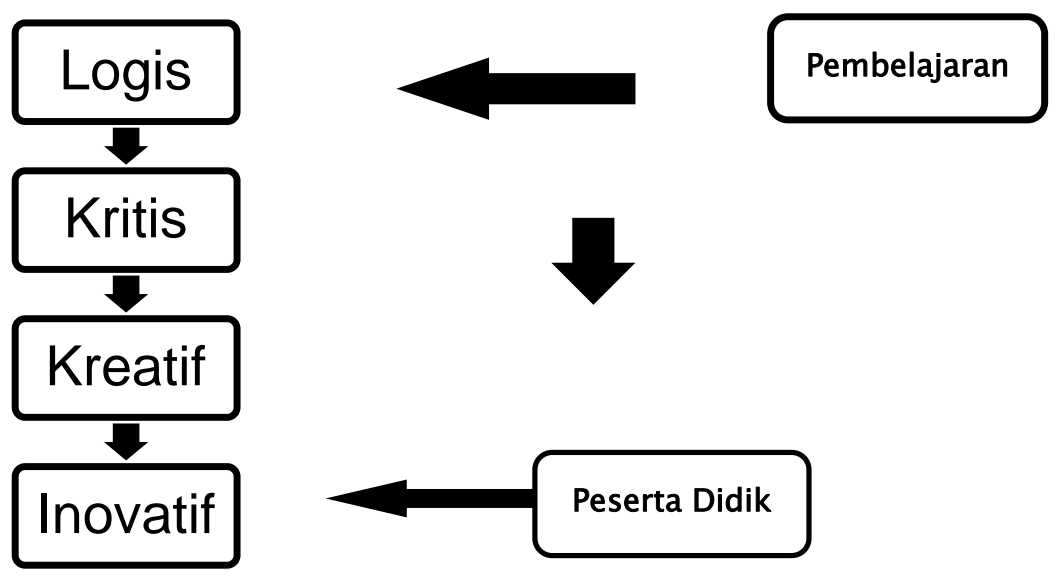

Gambar 1

Skema Karakter Logis, Kritis Kreatif dan Inovatif oleh Peserta Didik

\section{Konsepsi dan Karakteristik Pendekatan Saintifik dalam Pembelajaran Matematika}

Pembelajaran merupakan suatu proses interaksi antar siswa, antara siswa dengan Guru, dan siswa dengan sumber belajar pada lingkungan belajar. Maka dari itu perlu ada suatu pendekatan tepat yang dapat dipergunakan untuk membuat pembelajaran lebih efektif dan efisien mendekatkan antar variabel yang ada dalam interaksi edukasi. Isyu yang sering muncul dalam pembelajaran adalah siapa sentra dari kegiatan? Apakah guru atau siswa. Apabila guru yang menjadi narasumber, maka dikhawatirkan akan terjadi dominasi transfer pengetahuan dan kurangnya terjadi respon dalam pembelajaran, sehingga aktivitas belajar sulit terwujud. Melalui Permendikbud No 103 Tahun 2014 melalui Kurikulum 2013 kemudian digulirkan Pendekatan Saintifik dalam pembelajaran di kelas di mana Pendekatan Pembelajaran Saintifik adalah pendekatan pembelajaran yang dirancang agar siswa aktif mengkostruksikan konsep, prinsip atau teori melalui tahapan-tahapan mengamati, menanya, menalar, mengumpulkan informasi/mencoba, mencoba, menganalisis data dan menarik kesimpulan (mengasosiasi) dan mengomunikasikan konsep, prinsip atau teori yang ditemukan.

Karakteristik pendekatan saintifik yang dilakukan di sekolah dasar dicirikan dengan hal-hal berikut:1) berpusat pada siswa; 2)menggunakan prinsip keterampilan yang mendasarkan proses sains dalam penelaahan konsep, prinsip atau teori berupa langkah-langkah mengamati, menanya, menalar, mengumpulkan informasi/mencoba, mengasosiasi dan mengomunikasikan; 3) melibatkan proses-proses kognitif yang dapat merangsang perkembangan intelektual, khususnya keterampilan berpikir tingkat tinggi; 4)dapat mengembangkan karakter siswa. Kesemua itu memiliki tujuan dalam pelaksanaan pembelajarannya yakni 1) meningkatkan kemampuan intelektual siswa, khususnya kemampuan berpikir tingkat tinggi; 2) membentuk

kemampuan siswa dalam menyelesaikan suatu masalah secara sistematis; 3)terciptanya kondisi pembelajaran yang mendorong minat dan keinginan siswa bahwa belajar kebutuhan; 4) melatih keterampilan proses ilmiah siswa 
(mengamati, menanya, menalar, mengumpulkan informasi/mencoba, mengasosiasi dan mengomunikasikan); 5) diperolehnya hasil belajar siswa yang tinggi; 6) melatih siswa dalam mengomunikasikan ide; 7) mengembangkan karakter /sikap ilmiah siswa; 8) berkaitan dengan pencapaian tujuan.

Langkah-langkah untuk mencapainya dilakukan melalui kegiatan-kegiatan: a). mengamati (menyimak, menonton, mendengar, merasa, meraba, mencium dan sebagainya). b. menanya (kegiatan membuat dan mengajukan pertanyaan, Tanya jawab dan sebagainya); c. mengumpulkan informasi/mencoba (eksperimen, mencoba sesuatu, membuat sesuatu, mendemonstrasikan, meniru gerak, membaca berbagai sumber, mewawancara narasumber dan sebagainya). d. Menalar/mengasosiasi (aktivitas mengolah, menganalisis data, menemukan pola, menyimpulkan); e.mengomunikasikan (Presentasi, pajang karya, kunjung karya, menyajikan laporan secara lisan atau tertulis mulai dari proses, hasil dan kesimpulan). Kemendikbud (2013) karakteristik pendekatan saintifik yakni 1) materi pembelajaran berbasis pada fakta atau fenomena yang dapat dijelaskan dengan logika atu penalaran tertentu, bukan sebatas kira-kira khayalan, legenda, atau dongeng semata; 2) penjelasan guru, respon peserta didik, dan interaksi edukatif guru peserta didik terbebas dari prasangka yang serta merta, pemikiran subyektif, atau penalaran yang menyimpang dari alur pikir logis; 3) mendorong dan menginspirasi peserta didik berpikir secara kritis, analitis, dan tepat, dalam mengindentifikasi, memahami, memecahkan masalah; 4) mendorong dan menginspirasi peserta didik mampu berpikir hipotetik dalam melihat perbedaan, kesamaan, dan tautan satu sama lain dari materi pembelajaran; 5) mendorong dan menginspirasi peserta didik mampu memahami, menerapkan, dan mengembangkan pola berpikir yang rasional dan obyektif dalam merespon materi pembelajaran; 6) berbasis pada konsep, teori, dan fakta empiris yang dapat dipertanggungjawabkan; 7) tujuan pembelajaran dirumuskan secara sederhana dan jelas, namun menarik sistem penyajiannya.

Apabila dikaitkan dalam konteks pembelajaran matematika, Mahmudi (2015:561) menjelaskan pendekatan saintifik diterapkan untuk memfasilitasi peserta didik ketika mengumpulkan informasi sebagai bahan Pengetahuan yang berupa fakta, konsep atau prosedur dalam rangka mendapatkan bahan mencipta. Pembelajaran matematika melalui langkah-langkah pendekatan saintifik tidak hanya dipergunakan untuk memberikan masukan pengetahuan belaka, akan tetapi dapat pula dipergunakan oleh Guru untuk membentuk karakter siswa melalui internalisasi konsepsi metode yang dijalankan oleh berbagai kegiatan dalam pembelajarannya.

Pembelajaran matematika dengan menggunakan pendekatan saintifik digambarkan oleh As'ari (2015:8-15) terkait dengan langkah-langkah 5 M yang telah disebutkan di atas dapat diuraikan sebagai berikut:

a. Mengamati.

Pembelajaran Matematika, obyek pengamatannya dapat merupakan fenomena matematika dan dapat pula obyek kajian matematika. Misalnya saat mengamati kegiatan di Mini Market siswa bisa diarahkan untuk mengamati transaksi yang terjadi di sana sebagai suatu fenomena, karena melalui transaksi siswa dapat mengetahui mengenai konsep jual beli yang berhubungan dengan bilangan. 
b. Menanya.

Kemampuan bertanya penting sekali untuk dilatih dalam Pembelajaran Matematika, karena peserta didik setiap kali ia dihadapkan kepada bentukbentuk persoalan yang baru ia hadapi. Kegiatan menanya itu selanjutnya akan mendorong peserta didik untuk melakukan penyelidikan dan penelitian. Eksplorasi Penyelidikan dan Penelitian adalah kegiatan atau aktivitas yang merupakan langkah utama dalam setiap pembelajaran Matematika, karena matematika dikatakan sebagai Pure Science, yakni Ilmu yang dikembangkan untuk perkembangan Pengetahuan itu sendiri.

c. Menggali Informasi.

Menggali Informasi dapat dikatakan sebagai rutinitas pokok dalam pembelajaran Matematika karena fungsi utamanya adalah untuk melatih data yang bersifat kuantitatif dari berbagai Informasi. Karena itu berlatih menggali informasi merupakan sesuatu yang perlu mendapatkan penekanan dalam pembelajaran.

d. Mengasosiasi.

Mengasosiasikan adalah kata lain dari mengait-mengaitkan artinya siswa diharapkan untuk mengaitkan antara fakta yang satu dengan yang lain, terutama dalam hal penggalian persoalan yang bersifat matematis. Melalui Pembelajaran Matematika Guru melatih siswa membuat tabel, diagram, grafik dan lain-lain sebagai bentuk pemodelan daripada daftar persoalan yang didapat.

e. Mengkomunikasikan

Setiap kali melaksanakan Pembelajaran Matematika maka sebaiknya pengalaman mengalaminya menjadi bahan untuk dijadikan sumber belajar oleh peserta didik lainnya. Oleh karena itu perlu ada tindakan yang dilakukan Guru atau Pendidik untuk memberikan kesempatan pada siswa menyebarluaskan apa yang telah dia alami rasakan dalam setiap pembelajarannya. Kegiatan ini menjadi bahan refleksi dan evaluasi kepada segenap yang berkepentingan dalam bidang Pembelajaran. Dengan demikian Pendekatan Saintifik dalam Pembelajaran Matematika dapat kita konseptualisasi sebagai dasar pemikiran dalam penelitian ini adalah sebagai berikut

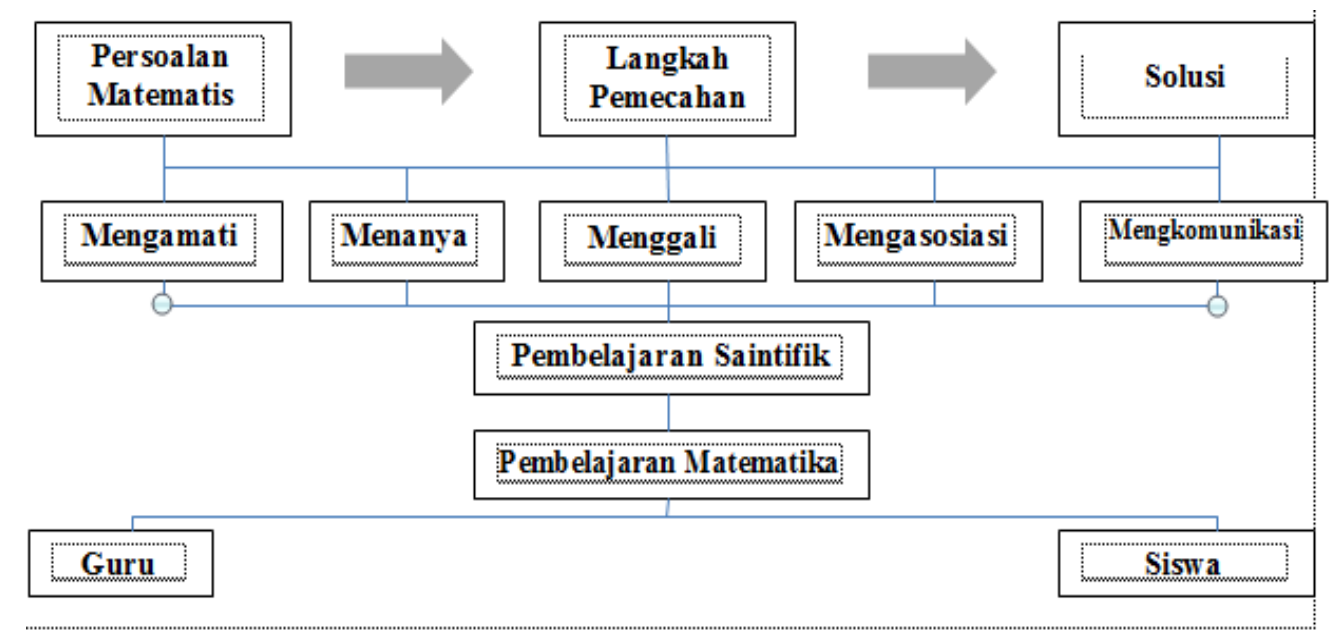

Gambar 2

Skema alur Pengkajian Persoalan Matematis 
Bagan tersebut menjelaskan bahwa ketika melaksanakan Pembelajaran Matematika Tenaga Pendidik akan menggunakan Pendekatan Saintifik melalui langkah-langkah Mengamati, Menanya, Menggali, Mengasosiasi, Mengkomunikasi untuk melaksanakan Pengumpulan Persoalan Permasalahan Matematis, Langkah-langkah memecahkan soal Matematika, dan Memberikan Solusi soal Matematika.

\section{Menumbuhkan Karakter Logis, Kritis, Kreatif dan Inovatif Melalui Penggunaan Pendekatan Saintifik dalam Pembelajaran Matematika.}

Mengenai bagaimana menumbuhkan karakter logis, kritis, kreatif, dan inovatif melalui langkah-langkah pendekatan saintifik dalam pembelajaran matematika akan terlihat dari bagaimana desain pembelajaran disusun Suryadi (2010:9) menjelaskan proses belajar matematika pada hakekatnya adalah merupakan pembentukan mental seseorang, jadi merupakan upaya mendesain pemikiran peserta didik agar memiliki kemampuan atau gambaran mentalitas seperti apa yang Guru inginkan. Tentunya dalam hal ini mentalitas atau karakter logis, kritis, kreatif dan inovatif tersebut.

Melalui lima langkah yang ditawarkan dalam Pendekatan Saintifik Pembelajaran Matematika kita akan melihat bagaimana karakter terbentuk berdasarkan pandangan teoritis. Berpikir Logis menjadi sesuatu capaian yang paling mudah untuk terlihat apakah telah tercapai atau tidak, di mana berpikir Logis dalam pembelajaran Matematika ini memiliki ciri: 1) Mampu berpikir menurut aturan Logika; 2) berpikir yang sistematis dan terstruktur; 3) Mampu mengklasifikasi dan mengkategorisasi; 4) mampu menganalisis secara numeric atau berdasarkan pengukuran-pengukuran (Pane dkk, 2013:14).

Indikator siswa secara empiris dikatakan memiliki karakter logis apabila; 1) mampu menghubungkan antar fakta; 2) mampu memberikan alasan; 3) mampu menyimpulkan apa yang telah ia pelajari. Dalam konteks Matematika siswa tersebut a) dapat menentukan sistem operasi penyelesaian matematis seperti apa yang ia harus pergunakan dalam sebuah soal dan mengkaitkan dari satu sistem operasi penyelesaian dengan sistem operasi penyelsaian yang lain; b) dapat memberikan dasar argumentasi secara teoritis matematis terhadap penyelesaian soal matematik yang ia lakukan; c) dapat mengambil memori langkah-langkah pengalaman belajar yang telah ia lakukan untuk dapat diterapkan pada soal matematika lainnya.

Berfikir kritis dalam matematika digambarkan sebagai suatu konsep yang memberikan ruang untuk; a) melakukan komparasi (perbandingan) dalam mengambil langkah untuk menyelesaikan suatu soal matematika; b) mempertanyakan mengenai efisiensi, efektivitas, 
dan manfaat pelaksanaan kegiatan belajar yang telah dilakukan; c) memetakan permasalahan dengan membuat kategorisasi dan sekuen atau urutan d) merekayasa berbagai proposi, rumus, hipotesis, dan teori, serta hukum, dan e) menyusun prediksi dengan menggunakan pengukuran pada indikator yang ada.

Melakukan kreasi inovatif dalam pembelajaran matematika dilakukan melalui a) penemuan solusi matematis secara mudah dan fleksibel; dan b) pemberian soal terbuka yang dapat diselesaikan melalui berbagai cara (Mahmudi, 2008: 47). Kesemua itu melalui Pendekatan Pembelajaran Saintifik akan dilakukan melalui ;

\section{Mengamati.}

Langkah mengamati akan memberikan pengetahuan pada siswa mengenai konsep fenomena sabagai data pengetahuan yang diamati/Kegiatan ini terlihat dalam pembelajaran mengenai pokok bahasan geometri. Sebelum siswa menyelesaikan persoalan maka ia terlebih dahulu harus mengamati obyek pengkajian apakah Bangun Datar atau Bangun Ruang? Apakah bentuk Bujur Sangkar, atau Kubus? Dan sebagainya. Pengamatan nyata sangat cocok bagi siswa SD dalam memahami konsep yang diturunan dari suatu proses induktif. Misalkan siswa mengamati sarang lebah terkait dengan segi banyak beraturan.

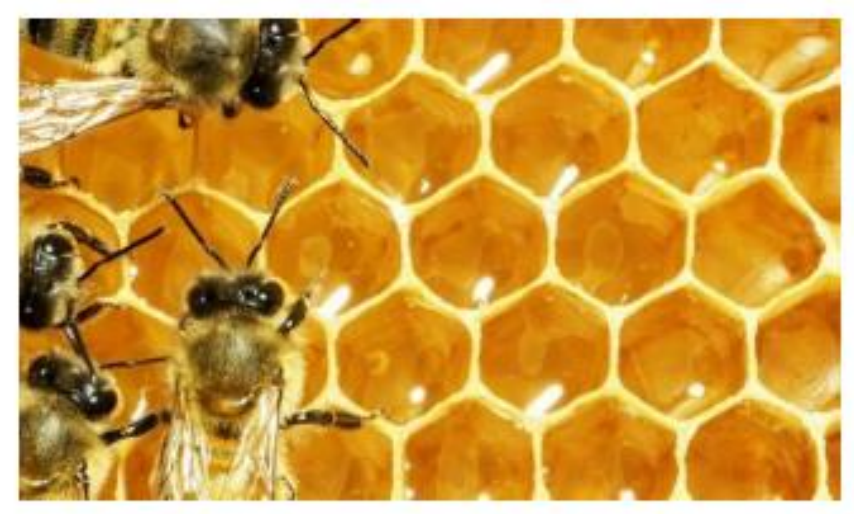

Gambar 1. Sarang Lebah

Sumber.jogya.tribunnews.com

Berkaitan dengan mengamati ini Brunner (Karso, 2014:1.12-1.15) proses belajar dalam Matematika akan terbagi dalam tiga tahap yakni; 1) Tahapan Enaktif atau berkegiatan, tahapan ini ketika Siswa akan melakukan suatu tindakan melalui gerak motoriknya untuk menanggapi lingkungan sekitarnya. 2) Tahap Ikonik atau penyimpanan data kesan inderawi yang dilakukan setelah melakukan tindakan sensorik motoric terhadap obyek pembelajaran; dan 3) Tahap simbolik setelah ia menyimpan data kesan inderawi kemudian akan dikomunikasikan dalam bentuk simbol dan bahasa. 


\section{Menanya.}

Melatih Siswa untuk selalu bertanya mengenai obyek yang sedang ia pelajari tentunya akan menjadi hal yang harus selalu diupayakan oleh seorang Guru. Dalam pembelajaran Matematika penting sekali dibangun komunikasi dialog interaktif dalam pembelajaran, karena tidak semua siswa memiliki kemampuan Kognitif yang sama, sehingga ini akan mendorong rasa ingin tahu, ketertarikan dan membagi pengetahuan secara bersama-sama. Misalnya; Pada suatu kelas ada seorang murid bertanya mengenai satu langkah apa yang ia harus lakukan untuk memecahkan persoalan Operasi Bilangan (i) $(-3)+5=$ ; (ii) $7+(-4)=$.... di mana untuk menyelesaikan tentunya dengan bertanya maka akan ada yang mendengarkan, menanggapi, dan ikut serta memikirkannya.

\section{Menggali Informasi}

Pembelajaran Matematika dikatakan sebagai keilmuan yang sifatnya Ilmu bantu dalam mempelajari Ilmu pengetahuan lainnya, maka dari penggalian informasi mengenai masukan input data yang berupa bilangan, ukuran, Simbol, dan Premis akan dipergunakan sebagai landasan informasi dalam pengkajian selanjutnya. Sebagai contoh siswa menggali informasi tentang unsur-unsur yang terdapat pada kubus dengan mengamati sebuah gambar kubus.

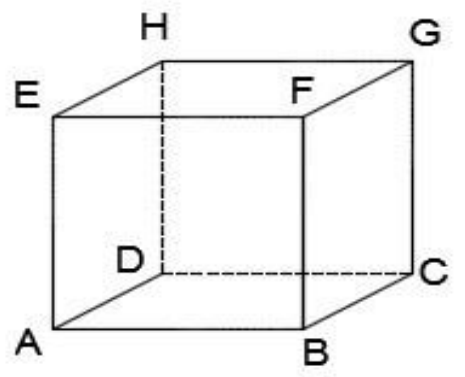

Gambar. 3

(Sumber: https://images.app.goo.gl/NpRGNw3tmpgND9TE7)

Pendekatan Saintifik melatih siswa untuk terbiasa melakukan pengumpulan data bilangan dan simbol melalui langkah-langkah pengukuran, pengamatan, dan olah panca indera.

\section{Mengasosiasi}

Memberikan kemampuan aplikatif Matematis pada anak atau peserta didik adalah suatu hal yang harus dilakukan, karena percuma kalau berbagai masukan bahan belajar berupa teori dan rumus ke dalam pemikiran anak tidak dapat diaplikasikan ke dalam berbagai aspek dalam kehidupannya sehari-hari. Pendekatan saintifik dalam pembelajaran Matematika hendak menyajikan langkah-langkah 
pembelajaran yang mampu mengasosiasikan bagaimana misal contoh penjelasan Rumusan Rumus Matematika ( bagaimanakan menuliskan rumus keliling pada lingkaran) ? Ukuran ?, Simbol?, Bilangan? Dan Premis? Ke dalam situasi kondisi kehidupan sehari-hari. Peserta didik diajak agar dapat memiliki kesan konkrit dalam pemikirannya mengenai gambaran abstrak rumus matematika melalui langkahlangkah pembelajaran berupa soal cerita, soal yang menampilkan audio visual contoh nyata kehidupan riil.

\section{Mengomunikasikan.}

Walaupun Pembelajaran Matematika lebih banyak menggunakan pemikiran, akan tetapi penting sekali mengajak siswa untuk dapat membagi pengalaman belajarnya kepada sekitarnya dan kepada Gurunya, Sehingga Siswa akan dipacu untuk berpikir logis, Kritis, Kreatif, dan Inovatif, karena siswa akan selalu membandingkan pengalaman belajarnya dengan siswa lainnya. Pendekatan Saintifik dalam Pembelajaran Matematika hendak memberikan kesempatan kepada siswa untuk dapat membagi cerita pengalaman belajar melalui kegiatan Presentasi di depan Kelas, Peragaan Produk Hasil Belajar, dan Penyusunan Laporan Hasil Belajar berupa Portofolio Hasil Belajar.

Maka dapat dikatakan penggunaan Pendekatan Saintifik telah memberikan latihan melalui bentuk-bentuk tindakan aktif yang akan mempengaruhi aspek kognitif, afektif dan psikomotorik dari Peserta Didik, sehingga internalisasi Bahan Materi Ilmu tidak hanya berupa kumpulan pengetahuan belaka, akan tetapi dapat pula sebuah pengalaman belajar.

\section{SIMPULAN.}

Setelah kita mengkaji mengenai bagaimana pendekatan saintifik dalam pembelajaran matematika secara lengkap, maka dapat ditarik kesimpulan bahwa: (1) pembentukan karakter logis, kritis, kreatif, dan inovatif melalui pendekatan saintifik dalam pembelajaran matematika dilakukan melalui langkah-langkah mengamati, menanya, mengumpulkan, mengumpulkan informasi/ mencoba, menalar/ mengasosiasikan, Mengomunikasikan yang dapat menginternalisasi peserta didik tidak hanya berupa bahan materi keilmuan berupa persoalan matematis, Langkah Pemecahan dan Solusi melalui, akan tetapi berupa pula pengalaman belajar. (2) karakter logis, kritis, kreatif, dan inovatif yang mampu menyikapi persoalan matematis, langkah pemecahan, dan solusi, sehingga peserta didik mampu menjadi Insan cendikia yang memiliki kemampuan keilmuan aplikatif yang dapat dijalankan dalam kehidupan sehari. 


\section{DAFTAR PUSTAKA}

Abdullah, I. H. (2016). Berpikir kritis matematik. Delta-Pi: Jurnal Matematika dan Pendidikan Matematika, 2(1).

As'ari, A. R. (2015). Mewujudkan Pendekatan Saintifik dalam Kelas Matematika. In Makalah dalam Seminar Nasional Pendidikan Matematika di Universitas Jember.

Asmani, J. M. M. (2011). Buku panduan internalisasi pendidikan karakter di sekolah. Diva Press.

Azizah, M., Sulianto, J., \& Cintang, N. (2018). Analisis keterampilan berpikir kritis Siswa sekolah dasar pada pembelajaran matematika kurikulum 2013. Jurnal Penelitian Pendidikan, 35(1), 61-70.

Dewi, A. K. T., Degeng, I. N. S., \& Hadi, S. (2019). Implementasi pendidikan nilai karakter di Sekolah Dasar melalui budaya sekolah. Jurnal Pendidikan: Teori, Penelitian, dan Pengembangan, 4(2), 247-255.

Karso, H. (2014). Pembelajaran Matematika di SD. Jakarta: Universitas Terbuka.

Kemendikbud. (2013). Pendekatan scientific (ilmiah) dalam pembelajaran. Jakarta: pusbangprodik.

Kosim, M. (2012). Urgensi pendidikan karakter. KARSA: Journal of Social and Islamic Culture, 19(1), 84-92.

Kunandar, (2009). Guru Profesional Implementasi Kurikulum Tingkat Satuan Pendidikan (KTSP) dan Sukses Dalam Sertifikasi Jakarta:RajaGrafindo Persada.

Mahmudi, A. (2008). Tinjauan kreativitas dalam pembelajaran matematika. Pythagoras: Jurnal Pendidikan Matematika, 4(2), 37-49.

Mahmudi, A. (2015). Pendekatan saintifik dalam pembelajaran matematika. Jurnal Pendidikan Matematika FMIPA UNY, 5.

Murni, A. Metakognisi Dalam Pembelajaran Matematika. Jurnal Prinsip Pendidikan Matematika, 1(2), 1-14.

Pane, L. Y., Kamid, K., \& Asrial, A. (2013). Proses Berpikir Logis Siswa Sekolah Dasar Bertipe Kecerdasan Logis Matematis dalam Memecahkan Masalah Matematika. Edu-Sains: Jurnal Pendidikan Matematika dan Ilmu Pengetahuan Alam, 2(2).

Saadulloh, Uyoh. (2004). Pengantar Filsafat Pendidikan. Bandung:Alfabeta.

Sanjaya, W. (2008). Kurikulum Dan Pembelajaran (Teori \& Praktek KTSP). Kencana. 
Sari, K. P., Neviyarni, S., \& Irdamurni, I. (2020). Pengembangan Kreativitas dan Konsep Diri Anak SD. Jurnal Ilmiah Pendidikan Dasar, 7(1), 44-50.

Syaodih, E. (1995). Psikologi Perkembangan Anak. Tersedia http://file. upi. edu/psikologi_perkembangan_anak. html [14 Februari 2015]

Supardan, Dadang. (2008). Pengantar Ilmu Sosial Suatu Kajian Pendekatan Struktural, Jakarta:Bumi Aksara.

Suyitno, I. (2012). Pengembangan pendidikan karakter dan budaya bangsa berwawasan kearifan lokal. Jurnal Pendidikan Karakter, (1)..

Tim Penyusun, (2016). Panduan Teknis Pembelajaran dan Penilaian Di Sekolah Dasar. Jakarta: Kementrian Pendidikan dan Kebudayaam Direktorat Jenderal Pendidikan Dasar dan Menengah Direktorat Pembinaan Sekolah Dasar. 